\title{
Kejadiandan Tata Laksana Mukositis pada Pasien Keganasan di RSUP Dr. Sardjito, Yogyakarta
}

\author{
Sri Mulatsih, ${ }^{*}$ Sri Astuti, ${ }^{* *}$ Yuliani Purwantika, ${ }^{* *}$ Julie Christine ${ }^{* *}$ \\ " SMF IKA Fakultas Kedokteran Universitas Gadjah Mada Yogyakarta \\ "Ilmu Kedokteran Gigi Anak FKG Universitas Gadjah Mada Yogyakarta
}

Latar belakang. Salah satu penyakit keganasan yang banyak diderita pada anak adalah leukemia, mencapai $30 \%-40 \%$ dari seluruh penyakit keganasan. Kemoterapi yang diberikan pada pasien leukemia dapat merusak sel-sel yang mempunyai aktivitas proliferasi berlebih, seperti sumsum tulang dan sel epitel mukosa mulut sehingga menyebabkan depresi sumsum tulang dan mukositis. Prevalensi mukositis yang terjadi pada pasien keganasan sekitar $30 \%-39 \%$.

Tujuan. Mengetahui apakah pengobatan mukositis yang telah diberikan di INSKA RSUP dr. Sardjito Yogyakarta cukup efektif serta untuk memberikan rekomendasi tata laksana mukositis berdasarkan bukti ilmiah.

Metode. Data mukositis diambil secara cross-sectional dengan observasi pada pasien keganasan yang mendapat kemoterapi di INSKA RSUP dr. Sardjito dan sudah mendapatkan perawatan nistatin drop dan triamsinolon orabase. Observasi dilakukan selama enam hari sejak tanggal 14 sampai dengan 20 juni 2007.

Hasil. Dari 33 pasien keganasan yang diamati dijumpai 10 anak (30,3\%) menderita mukositis dan 4 anak $(12,12 \%)$ menderita kandidiasis.

Kesimpulan. Perawatan mukositis dengan pemberian Candistin drop dan kenalog oral base pada pasien keganasan di INSKA RS dr. Sardjito belum dapat disimpulkan efektivitasnya karena waktu pengamatan yang singkat. Penelitian akan dilanjutkan dengan pengamatan secara longitudinal dan dilakukan perawatan mukositis sesuai protokol perawatan gigi dan mulut sebelum, selama dan sesudah kemoterapi. (Sari Pediatri 2008;10(4):230-5).

Kata kunci: keganasan, kemoterapi, mukositis.

$\mathrm{P}$ enyakit keganasan disebabkan adanya penyimpangan pertumbuhan sel-sel tubuh yang membelah secara tidak terkontrol dan menyerang organ tempat sel-sel keganasan

Alamat Korespondensi:

Dr. Sri Mulatsih, Sp.AK Sub. Bagian Hematologi-onkologi, SMF IKA FK UGM Fax: 0274583745 Telp:0274553142 tersebut berada, bahkan dapat terjadi penyebaran ke organ lain. ${ }^{1}$ Salah satu penyakit keganasan pada anak adalah leukemia, yang mencapai 30\%-40\% dari seluruh keganasan. Insidens leukemia mencapai 2,76/100.000 anak usia 1-4 tahun dan pada tahun 1996 didapatkan 5-6 pasien leukemia baru setiap bulan di RSUP Dr. Sardjito, Yogyakarta. ${ }^{2}$

Keganasan lain yang sering ditemukan pada anak adalah limfoma. Penyakit ini ditemukan hampir seper- 
tiga selain leukemia dan keganasan susunan saraf pusat. Di Indonesia angka kejadian limfoma maligna belum diketahui dengan pasti. ${ }^{3}$ Pengobatan keganasan secara umum terdiri dari terapi bedah, radioterapi, dan kemoterapi. Kemoterapi menjadi urutan pertama terapi yang sering dilakukan. Efek samping kemoterapi dapat merusak sel-sel yang mempunyai aktivitas proliferasi berlebih, seperti sumsum tulang dan sel epitel mukosa sehingga menyebabkan depresi sumsum tulang, mukositis, stomatitis, dan xerostomia. ${ }^{2}$

Prevalensi mukositis pada pasien keganasan adalah 30\%-39\%. ${ }^{4}$ Mukositis merupakan suatu proses reaktif yang menyerupai peradangan pada membrana mukosa orofaring akibat efek samping kemoterapi. ${ }^{5}$ Proses ini disebabkan adanya interaksi yang kompleks antara kerusakan jaringan mulut, keadaan lingkungan di rongga mulut, derajat penekanan sumsum tulang, dan faktor predisposisi intrinsik pasien. ${ }^{6}$ Keparahannya tergantung dari tipe terapi keganasan dan kondisi kebersihan mulut anak. ${ }^{5}$

Secara biologi dijumpai lima fase terbentuknya mukositis yaitu 1) fase inisiasi; kemoterapi berperan sebagai radikal bebas dapat merusak DNA, 2) fase message generation; terjadi pengaktifan faktor transkripsi (NFkB) yang akan mengatur jumlah proinflamatory cytokinel interleukin 1 beta (IL-1 $\beta$ ) dan tumor necrosis factor-alpha (TNF- $\alpha$ ). Sitokin IL-1 $\beta$ berperan untuk inflamasi dan dilatasi pembuluh darah sehingga kemungkinan besar dapat menambah konsentrasi kemoterapi pada daerah tersebut, sedangkan TNF- $\alpha$ menyebabkan kerusakan jaringan, 3) Fase signaling dan amplification; TNF- $\alpha$ mengaktifkan NFkB, mitogenactivated protein kinase (MAPK), dan sphyngomyelinase pathways yang dapat memperbesar kerusakan sel dan jaringan sehingga menyebabkan eritema dan atropi epitelial 4-5 hari setelah tahap awal kemoterapi. Trauma kecil dari aktivitas sehari-hari seperti menelan dan mengunyah dapat menyebabkan terjadinya ulserasi, 4) fase ulserasi/ bakteriologi; bila terjadi neutropenia diduga terjadi kolonisasi bakteri pada ulkus sehingga di dalam jaringan mukosa banyak mengandung endotoksin dan selanjutnya terjadi pelepasan IL-1 dan TNF-alpha, 5) fase penyembuhan; terjadi reepitelisasi pada ulkus yang ditandai dengan berpindahnya sel-sel epitel ke sebelah bawah dari pseudomembran (fibrin clot) ulkus kemudian berproliferasi sehingga menebal menjadi mukosa yang normal. ${ }^{8,9}$

World Health Organization (WHO) mengklasifikasikan mukositis menjadi empat skala yaitu, skala 1) kemerahan (eritema), nyeri ringan; skala 2) membran mukosa kemerahan dan timbul ulkus rata yang nyeri, pasien masih dapat makan; skala 3) ulkus terbentuk semakin dalam dan pasien hanya dapat makan dengan konsistensi cair dan skala 4) mukositis semakin parah, pasien sudah tidak dapat makan. Mulai skala 3, ulkus tersebut dapat terkontaminasi bakteri, jamur, dan virus. Hal ini dapat menimbulkan terjadinya kandidiasis jika ulcer ditumpangi jamur Candida albicans ${ }^{5,7}$ (Gambar 1).

Tujuan penelitian untuk mengetahui angka kejadian mukositis dan apakah pengobatan mukositis yang telah diberikan di INSKA RSUP Dr. Sardjito sudah efektif untuk memberikan rekomendasi tata laksana mukositis berdasarkan evidence based.

\section{Metode}

Penelitian cross-sectional dilakukan dengan observasi langsung. Data pasien keganasan dan yang mengalami mukositis menggunakan lembar isian penelitian yang sudah disiapkan. Subjek adalah seluruh pasien keganasan (33 anak) yang dirawat di INSKA RSUP Dr. Sardjito yang telah menerima kemoterapi dan perawatan mukositis dengan nistatin drop 100.000 $\mathrm{u} / \mathrm{ml}$ empat kali sehari serta triamsinolon oral base yang dioleskan 2-3 kali sehari setelah makan. Kriteria inklusi adalah semua pasien keganasan yang dirawat di INSKA RSUP Dr. Sardjito, usia 31 hari sampai dengan 15 tahun. Sedangkan kriteria eksklusi adalah orang tua yang tidak setuju untuk dilakukan pemeriksaan dan pengamatan. Bahan pemeriksaan menggunakan kaca mulut disposable dan alkohol. Waktu pengamatan dilakukan pada tanggal 14-20 juni 2007. Semua subjek dilakukan pemeriksaan untuk menentukan diagnosis mukositis. Pasien diminta membuka mulut, kemudian operator mengamati mukosa, lidah, gusi, palatum, dan dasar mulut.

\section{Hasil}

Dari 33 pasien keganasan yang dirawat di INSKA RSUP Dr. Sardjito, sebagian besar pasien terdiagnosis leukemia limfoblastik akut 23 sedang sisanya adalah leukemia mieloblastik akut 6 , limfoma non Hodgkin lymphoma 3, dan teratoma maligna 1 . Berdasarkan usia, sebagian besar pasien berusia antara 1 sampai 10 


\section{WHO's Oral Toxicity Scale}

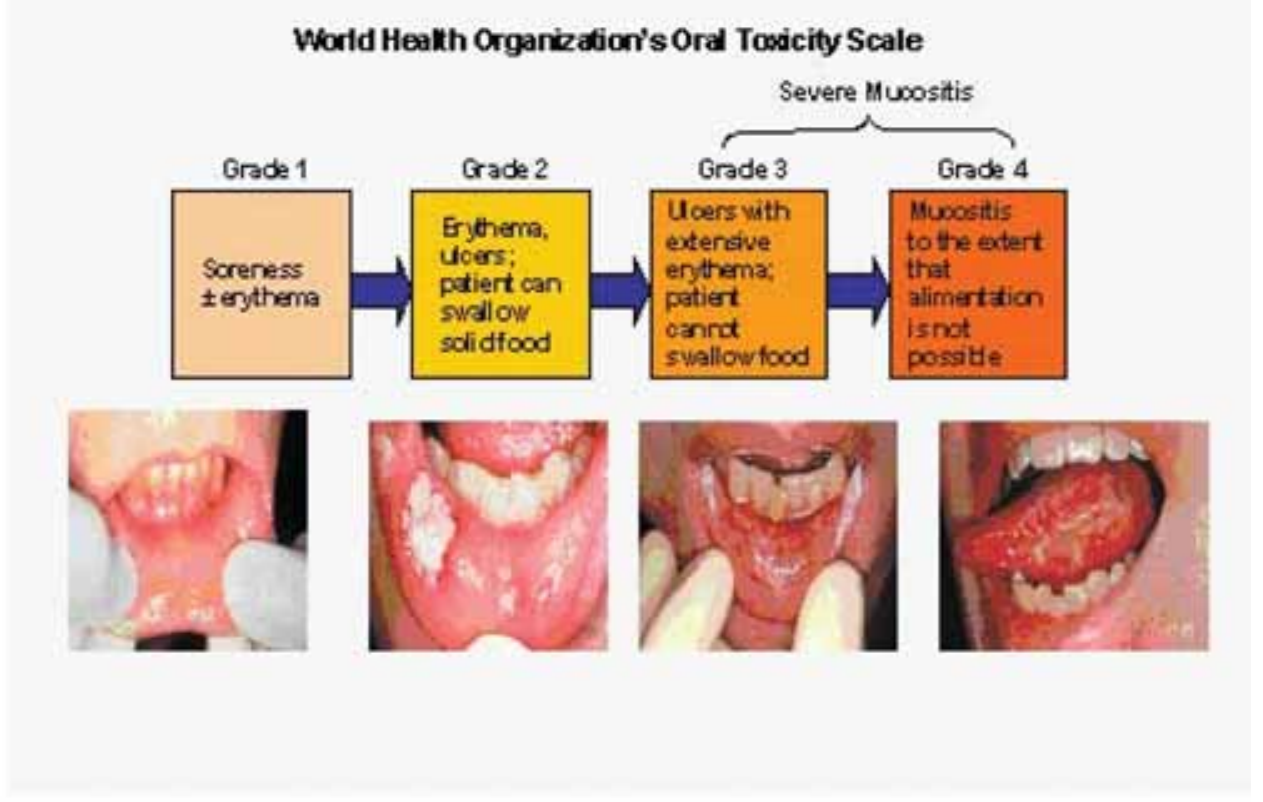

Gambar 1. Skala mukositis menurut WHO. ${ }^{10}$

tahun, 28 anak. Prosentase pasien laki-laki dan perempuan masing-masing 18 dan 15 (Tabel 1).

Pengamatan yang dilakukan di INSKA RSUD Dr. Sardjito dari tanggal 14-20 Juni 2007 secara konsekutif, dari 33 pasien keganasan 14 diantaranya menderita

Tabel 1. Karakteristik klinis pasien

\begin{tabular}{ll}
\hline Kriteria klinis & Jumlah \\
\hline $\begin{array}{l}\text { Jenis kelamin } \\
\quad \text { laki-laki } \\
\text { perempuan }\end{array}$ & 18 \\
& 15 \\
Usia (tahun) & \\
$\quad<1-\geq 10$ & 28 \\
$1-<10$ & 5 \\
& \\
Diagnosis & \\
$\quad$ leukemia limfoblastik akut* & 23 \\
leukemia mieloblastik akut** & 6 \\
limfoma non-Hodgkin ${ }^{* * *}$ & 3 \\
teratoma maligna & 1 \\
\hline${ }^{*}$ LLA, ${ }^{* *}$ LMA, ${ }^{* * * N H L}$ &
\end{tabular}

mukositis (Gambar 2 dan 3). Jenis mukositis yang ditemukan berdasarkan klasifikasi WHO adalah skala satu 4 anak, skala dua 2 anak, skala tiga 8 anak, dan skala 4 tidak ditemukan. (Tabel 2)

Berdasarkan diagnosis leukemia, pasien yang terbanyak menderita mukositis adalah LLA dengan derajat paling banyak skala 3. Pasien leukemia tersebut sebagian besar berada pada fase kemoterapi induksi dan konsolidasi. Demikian juga untuk pasien LMA yang mengalami mukositisis, semua dalam fase kemoterapi induksi dan intensifikasi.

\section{Diskusi}

Pasien keganasan dikategorikan dalam tiga kelompok yang memerlukan perawatan rongga mulut yang berbeda. Pasien dengan risiko tinggi merupakan pasien yang mudah terkena infeksi dan perdarahan di rongga mulut. Pada sumsum tulang dan darah tepinya banyak mengandung sel-sel leukemik yang berada dalam tahap blast critis. Pasien keganasan tersebut segera akan diberi 
Sri Mulatsih dkk: Kejadian dan Tata Laksana Mukositis pada Pasien Keganasan Di RSUP Dr. Sardjito

Tabel 2. Jenis mukositis berdasarkan klarifikasi klinis WHO

\begin{tabular}{llcccccc}
\hline No & Diagnosis & Jumlah & & & Mukositis & \\
\cline { 6 - 7 } & & pasien & Skala 1 & Skala 2 & Skala 3 & Skala 4 & Total \\
\hline 1. & LLA & 23 & 4 & 1 & 6 & 11 \\
2. & LMA & 6 & & 1 & 1 & 2 \\
3. & NHL & 3 & & & 1 & 1 \\
4. & Teratoma & maligna & 1 & & & - & 0 \\
\hline & Jumlah & 33 & 4 & 2 & 8 & \\
\hline
\end{tabular}

Keterangan: LLA = leukemia limfoblastik akut, LMA = leukemia mieloblastik akut, NHL = limfoma non-Hodgkin

kemoterapi yang dapat menyebabkan myelosuppressed. Perawatan dental pada kelompok penyakit keganasan memerlukan kerja sama yang baik antara dokter yang merawat dengan pasien dan keluarganya. Infeksi mulut dapat dirawat dengan antibiotik spektrum luas melalui intra vena. Pada pasien yang tidak menunjukkan keganasan tapi masih ada myelosuppressed (risiko sedang), mukositisis terjadi empatbelas hari setelah diberi kemoterapi sehingga perawatan gigi harus ditunda. Perawatan gigi dapat dilakukan duapuluh satu hari setelah pasien diberi kemoterapi. Pemeriksaan laboratorium untuk mengetahui jumlah leukosit dan trombosit harus dilakukan sebelum melakukan perawatan rongga mulut. Perawatan dapat dilakukan bila jumlah leukosit kurang dari $3500 \mathrm{sel} / \mathrm{mm}^{3}$ dan jumlah platelet kurang dari $100.000 \mathrm{sel} / \mathrm{mm}^{3}$. Pasien dengan risiko ringan, pasien sudah mengalami penyembuhan sehingga perawatan gigi dapat dilakukan sesuai dengan protokol perawatan anak sehat. ${ }^{12}$

Pemeriksaan gigi sebaiknya dilakukan sebelum kemoterapi. Pemeriksaan radiologik diawali dengan

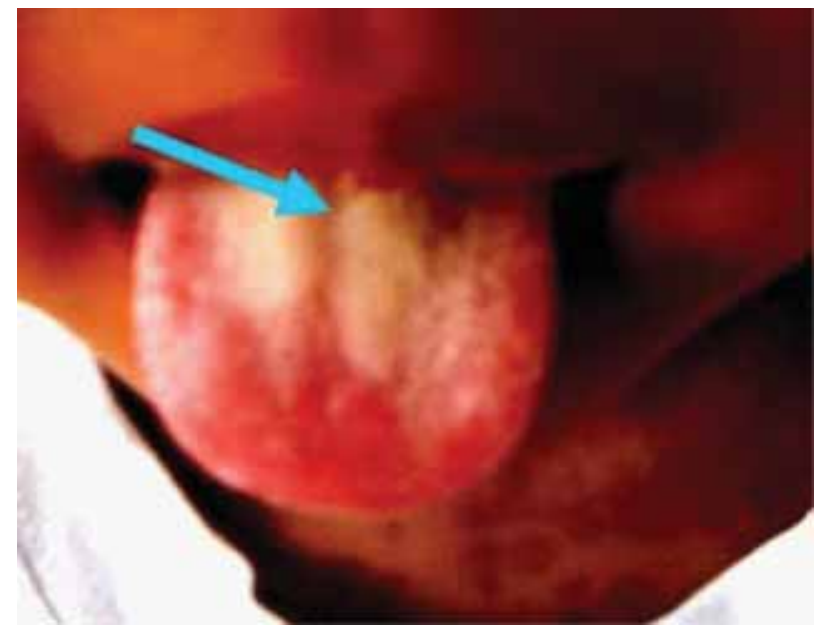

Gambar 2. Mukositis pada lidah pasien ALL pemeriksaan panoramic dan bite-wing (periapikal), pencabutan pada gigi dengan prognosis buruk, tumpatan sementara pada semua karies, sikat gigi dengan pasta gigi yang mengandung fluor dua kali sehari, anak dengan risiko karies tinggi sebaiknya menggunakan obat kumur yang mengandung klorheksidin $0,12 \%$ dengan dosis dua kali sehari. Selama kemoterapi diberikan obat kumur yang mengandung klorheksidin 2 kali sehari. Menyikat gigi dihentikan sementara jika lesi oral terasa nyeri. Pemberian nistatin (100.000 unit $/ \mathrm{ml}$ ) suspensi oral 4 kali sehari jika ada tanda-tanda oral candidiasis dan diberikan acyclovir topical jika terdapat tanda infeksi virus herpes simpleks. Apabila terjadi xerostomia diberikan saliva artifisial dan sodium bicarbonat rinse 5\%. Pada masa penyembuhan dapat dilakukan perawatan gigi dasar yang meliputi sikat gigi dengan pasta fluor 2 kali sehari, berkumur dengan larutan fluor satu kali sehari, penggunaan dental floss 1 kali sehari, saran dan konseling diet, serta kontrol 1-6 bulan sekali dan topikal aplikasi fluor. Kontrol berkala untuk monitor

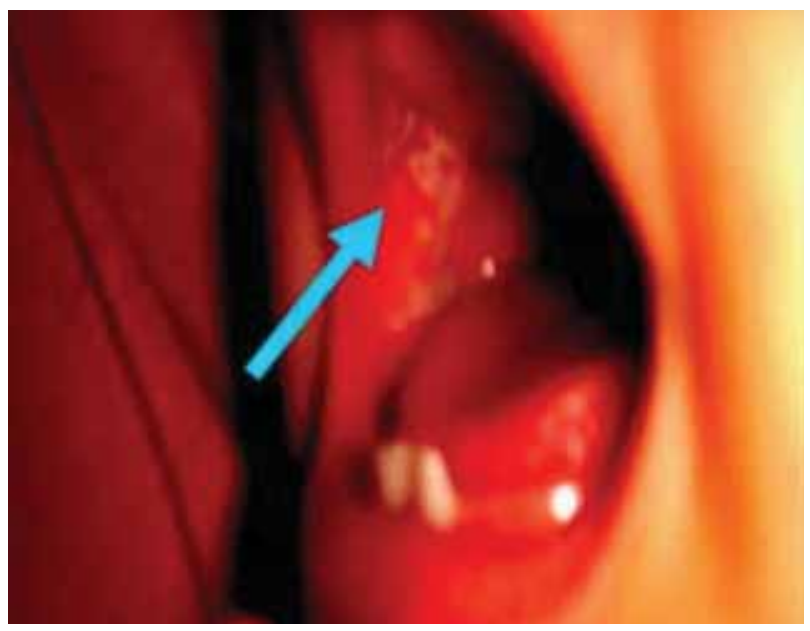

Gambar 3. Mukositis pada mukosa pipi pasien ALL 
pertumbuhan gigi dan tumbuh kembang wajah (lihat lampiran). ${ }^{13}$

Pasien dengan mukositis skala 3 dan 4 tidak dapat makan karena terasa sangat nyeri, maka perlu pemberian obat kumur yang mengandung anestesi misalnya kombinasi benzokain atau tetracain spray. Analgesik sistemik dapat digunakan apabila berkumur dengan larutan anestesi tidak berhasil mengurangi rasa nyeri. ${ }^{5}$

Pasien keganasan di Amerika Serikat yang sudah mendapatkan kemoterapi sekitar 40\% kasus menderita mukositis. ${ }^{14}$ Observasi di INSKA RSUP Sardjito didapatkan 42,4\% pasien keganasan yang mendapat kemoterapi menderita mukositis. Angka kejadian yang cukup tinggi ini mungkin karena pemakaian nistatin dan triamsinolon orabase yang tidak sesuai dengan indikasi. Triamcinolone acetonide adalah preparat kortikosteroid yang merupakan bahan utama triamsinolon orabase dapat menyebabkan ulkus semakin parah, apalagi yang disebabkan oleh jamur, virus, dan bakteri. Triamsinolon orabase yang diberikan pada lesi yang telah terkontaminasi oleh jamur akan semakin memperparah lesi tersebut. Indikasi triamsinolon orabase hanya untuk mengurangi gejala dari lesi akibat inflamasi dan trauma sehingga hanya digunakan pada mukositis skala 1 dan 2. Penggunaan nistatin juga perlu diperhatikan karena hanya digunakan ketika mukositis sudah terkontaminasi oleh jamur sesuai dengan indikasi nistatin untuk pengobatan jamur kandida di rongga mulut. Kepedulian dan pengetahuan orangtua akan kebersihan mulut merupakan faktor yang sangat penting dalam mempengaruhi keparahan mukositis pada pasien keganasan. ${ }^{14}$

Pengamatan pada efektifitas perawatan mukositis dengan pemberian nistatin drop dan triamsinolon oral base pada pasien keganasan di INSKA RS dr. Sardjito belum dapat disimpulkan melalui pengamatan sesaat. Diperlukan penelitian lanjutan secara longitudinal dan memenuhi jumlah subjek yang diperlukan.

\section{Daftar Pustaka}

1. Permono B, Ugrasena IDG. Leukemia akut dalam: Buku Ajar Hematologi-Onkologi Anak. Yogyakarta: IDAI; 2005.h.236-45.

2. Sutaryo. Prinsip kemoterapi pada kanker anak. Dalam: Permono B, Sutaryo, Ugrasena IDG, Windiastuti E, Abdulsalam M, penyunting. Buku Ajar HematologiOnkologi Anak. Yogyakarta: IDAI; 2005.h.227-34.

3. Sudarmanto BT, Mudrik, Sumantri AG. Limfoma maligna. Dalam: Buku Ajar Hematologi-Onkologi Anak. Yogyakarta: IDAI; 2005.h.248-54.

4. Ilgenli. T, Oren. H, Uysal. K. The acut effect of chemotheraphy upon the oral cavity: prevention and management. Turkish J of Cancer 2001;31:93-9.

5. Spijkervet FKL. Mukositis akibat radiasi pencegahan dan pengobatan (terjemahan.). Edisi ke-1. Jakarta: KDT; 1996.h.1-3.

6. Meraw SJ, Reeve CM. Dental considerations and treatment of the oncology patient receiving radiation therapy. JADA 1998;129:201-5.

7. Hsiao G, Sonis ST. Oral mucositis. Dalam: Mithell BM, Joane L, penyunting. Interactive textbook on clinical symptom research. Philadelphia: 1999.h.9-10.

8. Köstler WJ, Hejna M, Wenzel C, Zielinski CC. Oral mucositis complicating chemotherapy and/or radiotherapy: options for $\mathrm{p}$ revention and treatment. CA Cancer J Clin 2001;51:290-315.

9. Woo,S.B. Chemotherapy-induced oral mucositis, 2006. Didapat dari: http://www.eMedicine.com. Diakses tanggal: 20/6/2007.

10. Stiff PJ. Coding for mucositis. Loyola University Medical Center September 30, 2005. Didapat dari: http://cdc. gov/nchs/ppt/icd9/att_mucositis_sep05.ppt. Diakses tanggal: 12/12/2007.

11. Brown J, Byers T, Thompson K, Eldridge B, Doyle C, Williams AM. Nutrition during and after cancer treatment: a guide for informed choices by cancer survivors. CA Cancer J Clin 2001;51;153-81. Didapat dari: http://caonline.amcancersoc.org/cgi/content/full/51/3/ 153. Diakses tanggal: 5/12/ 2007.

12. Sonis, Fazio, Fang. Hematologic malignancies. Edisi ke-1. Philadelphia: WB Saunders Company; 1984.h.324-38.

13. Cho SY, Cheng AC, Cheng MCK. Oral care for children with leukemia. HKMJ 2000;6:203-8.

14. Little JW, Falace DA, Miller CS, Rhodus NL. Dental management of the medically compromised patient. Edisi ke-6. St Louis: Mosby; 2002.h.403-6. 
Lampiran. Protokol perawatan rongga mulut anak dengan leukemia akut

\begin{tabular}{ll}
\hline Fase Penyakit & Perawatan \\
\hline & Pemeriksaan gigi dengan rontgen panoramic dan bite-wing (periapikal). \\
& Pencabutan pada gigi dengan prognosis buruk. \\
Pre-kemoterapi & Tumpatan sementara pada semua karies. \\
& Anat gigi dengan pasta gigi yang mengandung fluoride 2x sehari. \\
& $0,12 \%$ dua kali sehari. \\
& Penggunaan obat kumur yang mengandung klorheksidin 2x sehari. \\
& Menyikat gigi dihentikan sementara jika lesi oral terasa nyeri. \\
& Berikan Nistatin (100.000 unit/ml) suspensi oral 4x sehari jika ada tanda-tanda oral \\
& candidiasis. \\
& Berikan acyclovir topical jika ada tanda-tanda infeksi herpes simpleks virus. \\
& Bila terjadi xerostomia berikan saliva artifisial dan sodium bicarbonat rinse $5 \%$. \\
Pasien dalam masa perawatan $\%$ & Perawatan gigi dasar harus meliputi : \\
& Sikat gigi dengan pasta fluorid 2x sehari. \\
& Kumur dengan larutan fluorid 1x sehari. \\
& Penggunaan dental floss 1x sehari \\
& Saran dan konseling diet \\
& Kontrol 1-6 bulan sekali dan topikal aplikasi fluor. \\
& Perawatan pasien dengan protokol normal jika pasien dalam penyembuhan total, kecuali \\
pada perawatan yang membutuhkan pembedahan. & \\
Masa remisi & Kontrol berkala untuk monitor pertumbuhan gigi dan tumbuh kembang fasial. \\
\hline
\end{tabular}

